\title{
Denosumab: A potential new treatment option for recurrent Aneurysmal Bone Cyst of the spine
}

\author{
Arvind G. Kulkarni* and Ankit Patel \\ Mumbai Spine Scoliosis \& Disc Replacement Centre, Department of Orthopedics Surgery, Bombay Hospital and Medical Research \\ Center, 400002 Mumbai, India
}

Received 4 September 2018, Accepted 10 February 2019, Published online 1 April 2019

\begin{abstract}
ABCs are expansile osteolytic lesions typically containing blood-filled spaces separated by fibrous septae. Standard treatment includes surgical resection or curettage and packing; however, for some spinal lesions, the standard approach is not optimal. One therapeutic strategy is to treat spinal ABC with an agent that targets a pathway that is dysregulated in a disease with similar pathophysiology. Denosumab, a human monoclonal antibody to RANKL is effective in the treatment of GCT's. Spinal ABCs are a therapeutic challenge and local recurrence is a concern. We report a case of aggressive recurrent $\mathrm{ABC}$ of dorsal spine in a 14-year old female with progressive neurologic deficit who underwent surgical excision and decompression with a recurrence in a short period for which a decompression and fixation was done. She had a recurrence after an asymptomatic period of 6 months and neurologic worsening. Having ruled out use of embolization and radiotherapy, a remission was achieved by treatment with Denosumab using the regimen for GCTs for a duration of 6 months. Follow-up MRI and CT scans at 24 months following inception of Denosumab depicted complete resolution and no recurrence. We conclude that Denosumab can result in symptomatic and radiological improvement in the recurrent locally aggressive ABC and may be useful in selected cases. Long-term results are mandatory to confirm the efficacy of Denosumab and to evaluate local recurrence after stopping Denosumab.
\end{abstract}

Key words: Donesumab, Spine, Aneurysmal bone cyst, Thoracolumbar spine, Aggressive.

\section{Introduction}

ABCs are expansile lesions accounting for approximately $15 \%$ of all primary spinal tumours [1-3]. Multiple treatment modalities like intra-lesional excision, Selective Arterial Embolisation, injection with sclerosing-agents and radiation have been attempted with variable improvement and recurrence rates. However, these approaches may be associated with severe morbidities, where lesion is in the thoracic spine $[4,5]$.

Giant-cells that occur in ABCs are positive for markers of true osteoclasts [6,7]. The osteoclast secretes receptor activator of nuclear factor k-B ligand (RANKL) [8-12]. Here, we report a case of recurrent $\mathrm{ABC}$ of the thoracic-spine that achieved resolution after treatment with Denosumab, a human monoclonal-antibody to RANKL that is effective in the treatment of GCTs [9,10,12] and ABCs [6,13-16].

\footnotetext{
*Corresponding author: drarvindspines@gmail.com
}

\section{Case report}

A 14-year-old female presented with unsteady gait and back-pain. She had undergone two previous spinal surgeries in the recent past at another hospital. The previous medical-records showed that the girl developed insidious-onset, progressive spastic sensory-motor paraparesis. MRI of the dorsal-spine (Figure 1) suggested an intensely enhancing cystic-haemorrhagic septate expansile lesion $(5.7 \times 3.1 \mathrm{~cm})$ involving D5 vertebra with epidural extension (D4-D5) causing marked spinal-cord compression and oedema. The lesion was hypo-hyperintense on T2WI, with intense heterogeneous enhancement. T1 hyperintense signals suggested haemorrhagic component. SAE was ruled out by the interventional neuroradiologist due to potential risk of vascular insult to the spinal-cord. An intra-lesional excision was done and D4-D6 unilateral pedicle screw-rod fixation was performed. After 2 days of initial neurological improvement, the patient developed neurological worsening, which was attributed to a 


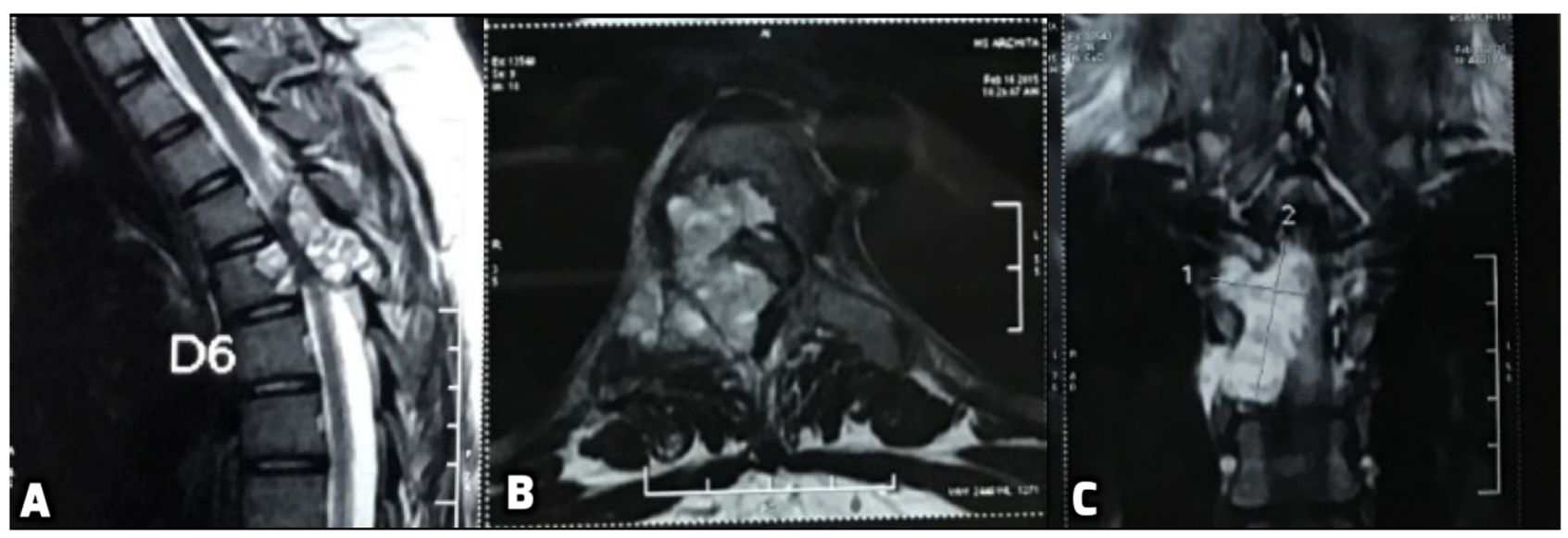

Figure 1. First Pre-operative MRI (A) revealing an intensely enhancing cystic cum haemorrhagic septate expansile bony lesion $(5.7 \times 3.1 \mathrm{~cm})$ involving the posterior part of D5 vertebral body, right lamina, right pedicle and transverse process with epidural extension (D4-D5) causing marked spinal cord compression and underlying cord oedema. (B) Axial T2 MRI scan depicts the encroachment of the right half of body and posterior elements with compression of the spinal cord. (C) Coronal image through the spinal canal showing intense enhancement on $\mathrm{T} 2 \mathrm{image}$ with fluid levels.

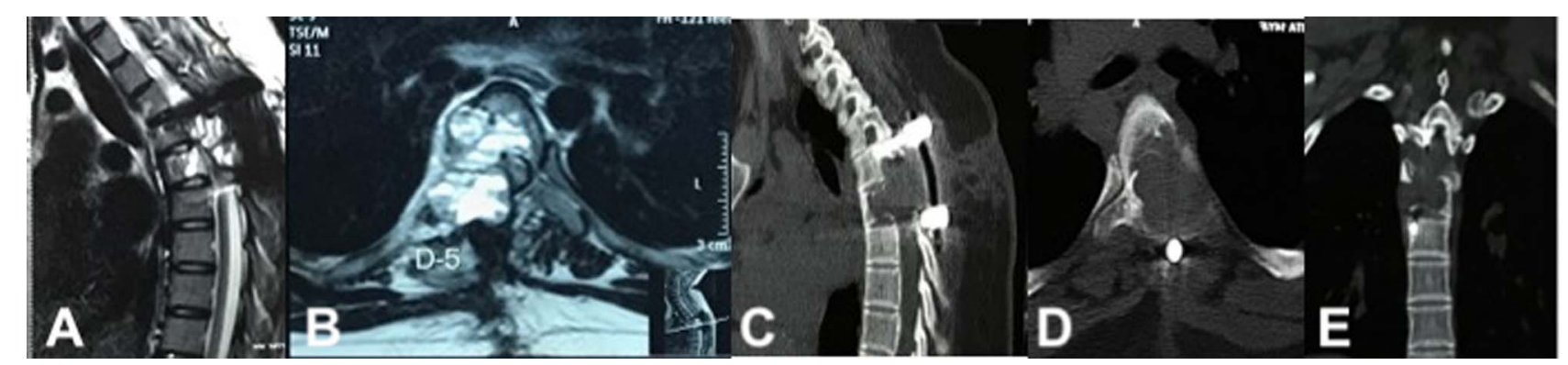

Figure 2. Post-operative day 2 MRI showing surgical mass compressing dorso-laterally from right (A, B), CT scan depicting the extent of bony destruction $(\mathrm{C}-\mathrm{E})$ with pedicle screw fixation and excision of $\mathrm{ABC}$.

compressive surgical mass. Following re-exploration and removal (Figure 2), the patient had recovery for a period of 2 months, but again worsened neurologically. MRI revealed an increase in the epidural mass with spinal cord-compression. The patient presented to the authors at this stage. A revision decompression was performed and circumferential reconstruction was done with a mesh-cage and bilateral pedicle-screwrod fixation from D1 to D8. She made a significant neurologic recovery (Figure 3). Histopathology revealed an ABC (Figure 4). After 3 months, the patient had recurrent symptoms again in the form of back-pain and unsteadiness of gait that was explained by an epidural lesion $(3.4 \times 2.5 \mathrm{~cm})$ compressing the spinal cord with myelomalactic changes (Figure 5). The situation had a significant negative psychological impact on the young girl. Alternative treatment options were sought and finally treatment with Denosumab was offered to the patient after thorough counselling regarding the expected benefits, experimental nature and possible adverse-effects.

Treatment was begun using the regimen described for treating GCT [9-11] (120 mg sc D1, 8, 15, 28 and then monthly).
She improved within a month's time. MRI at 2 months of therapy documented significant resolution of epidural compressive mass and MRI at 6 months depicted complete resolution (Figure 6). Denosumab treatment was discontinued at 6 months and scans at 1 and 2 years showed no recurrence. CT at 2 years showed ossification of the lesion with remodelling of the spinal canal and incorporation of the mesh-cage (Figure 7).

\section{Discussion}

$\mathrm{ABCs}$ are generally rare tumorous lesions of the spine, but can lead to devastating symptoms as they are capable of destructive growth. Common treatment options for $\mathrm{ABCs}$ include surgical resection, curettage and filling, selective arterial embolisation, total arterial embolisation or radiotherapy. For spinal ABCs, however, some of these options entail considerable risks. Sclerosant therapy was not considered in our patient as the cortices were eroded following previous 


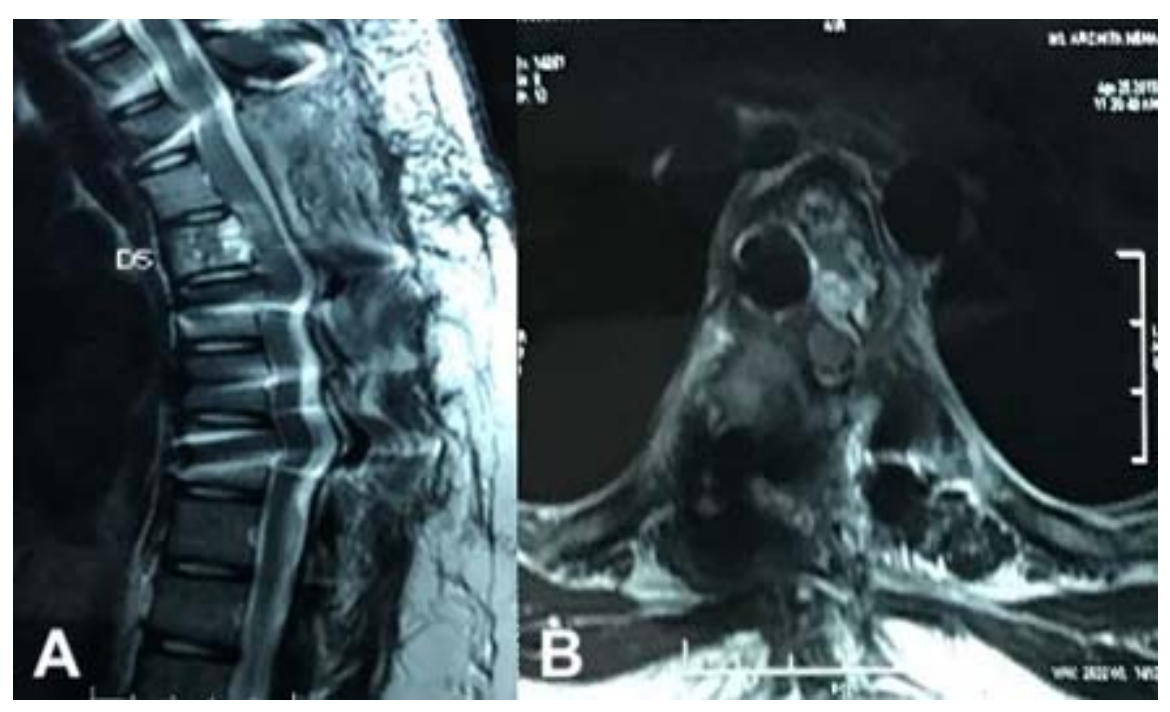

Figure 3. Post second intra-lesional resection MRI showing removal of epidural compressive mass. Dorsal spinal cord decompressed ventrodorsally on sagittal (A) and axial views (B) No evidence of enhancing fluid filled lesion on T2WI of MRI.

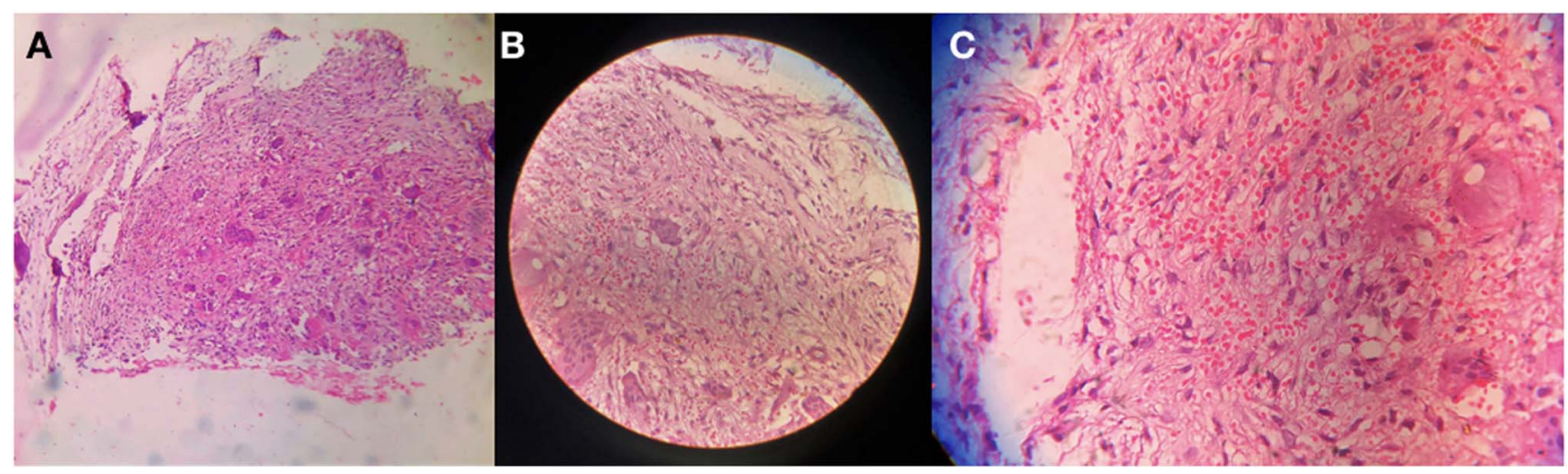

Figure 4. Hematoxylin and eosin-stained slide, scanner view showing Cystic spaces surrounded by fibrous tissue proliferation along with multiple osteoclastic giant cells at $4 \times$ magnification (A). $10 \times$ magnification (B) and $40 \times$ magnification (C) showing cystic spaces filled with few rbcs lined by bland fibroblast and dense fabricollagenous tissue in the surrounding with proliferating capillaries and numerous osteoclastic giant cells.

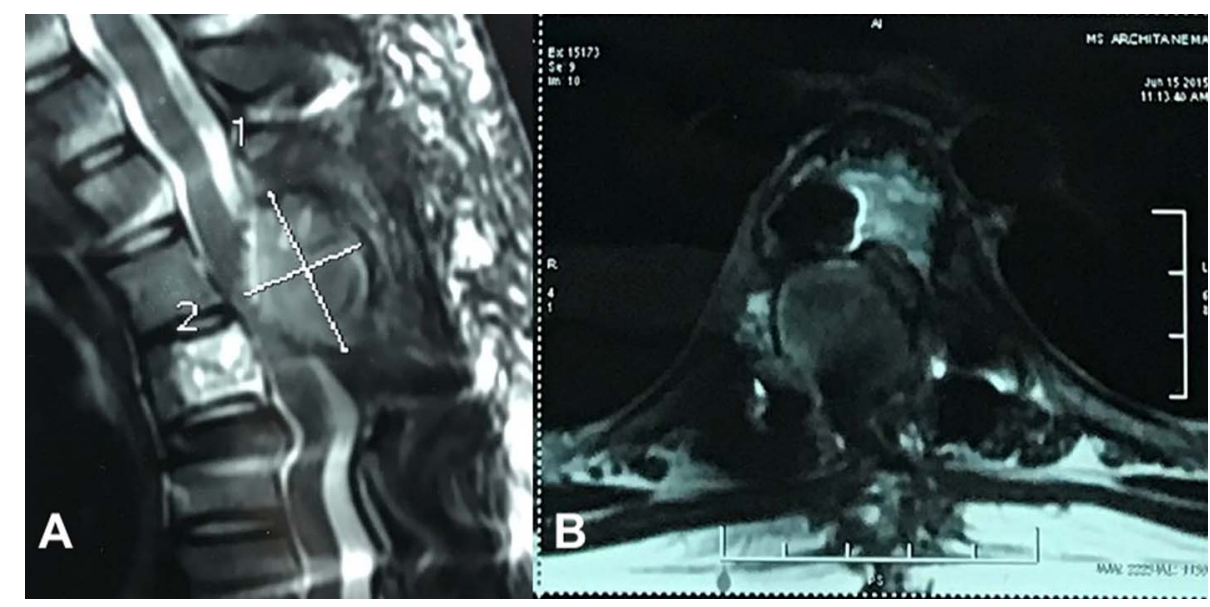

Figure 5. MRI after second recurrence showing Epidural compressive mass (cross-hairs) from the right side with underlying Myelomalacia of the spinal cord with ventral displacement on sagittal (A) and axial scans (B). 


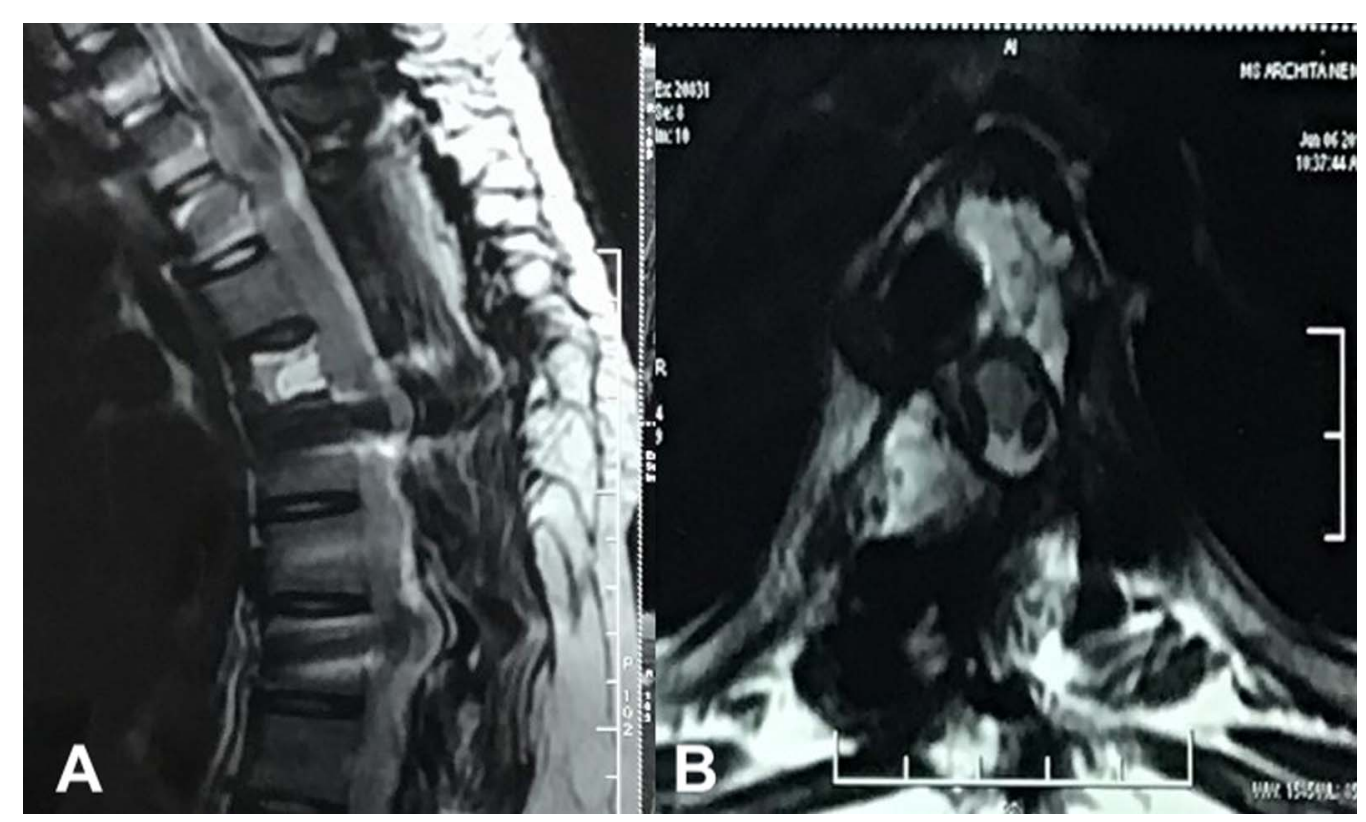

Figure 6. A 6-month follow-up MRI post completion of Denosumab therapy. (A) shows a sagittal T2WI MRI image with resolution of previous dorsal compressive mass and (B) axial image of the decompressed spinal cord.

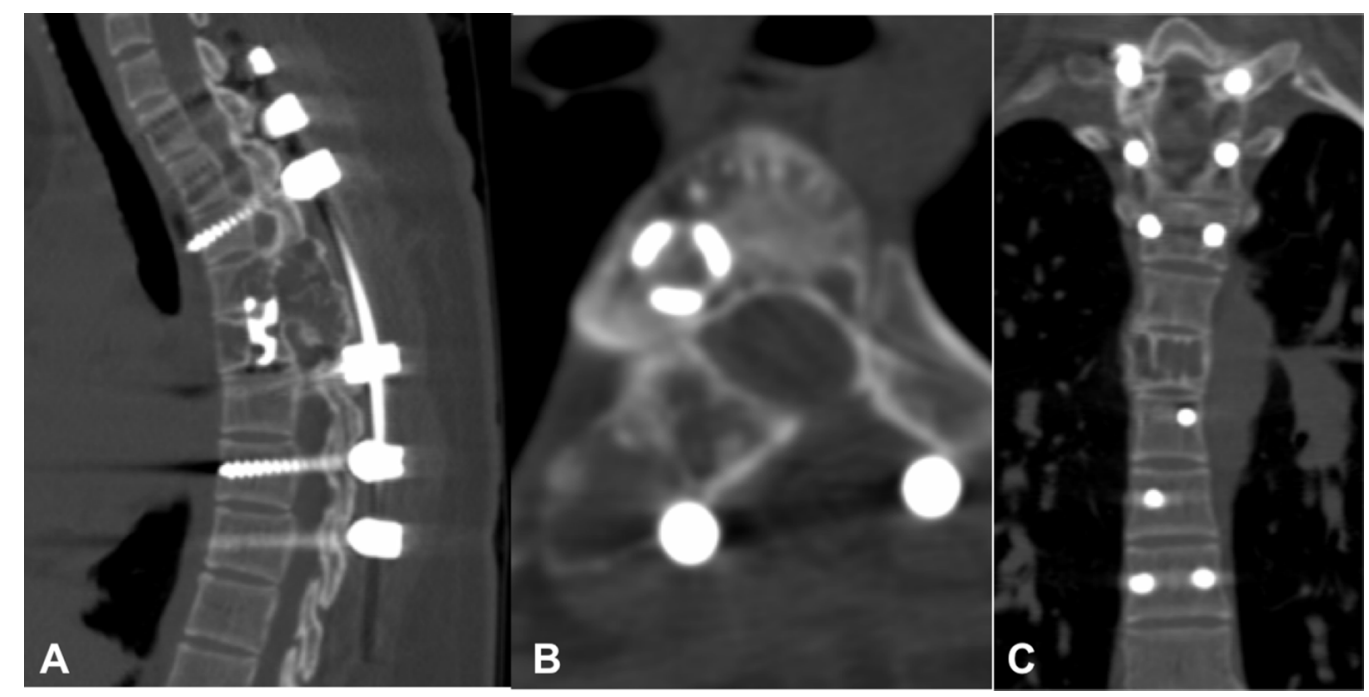

Figure 7. 2-year follow-up CT scan. Ossification of the lesion with remodelling of the spinal canal and incorporation of Harm's cage seen on Sagittal (A), axial (B) and Coronal (C) images.

surgical excisions, and hence there was a risk of seepage of sclerosant into neuro-vascular elements leading to catastrophic complications [13].

Denosumab, a human monoclonal-antibody, binds to a cytokine receptor activator of nuclear factor-kappa Bligand (RANKL) and prevents the action of agonists acting through RANKL-receptors. This prevents the subsequent activation and proliferation of the osteoclasts [14]. Seven patients have been successfully treated with Denosumab in addition to our patient [6,13-15,17] (Table 1). Clinical trials have shown that Denosumab is effective in reducing tumour mass in case of refractory, recurrent or inoperable GCT $[9,10]$. Denosumab also inhibits normal bone remodelling and an important toxicity of Denosumab is osteonecrosis of the jaw [18-20]. Again, osteopetrosis or osteosclerosis after use of Denosumab in young patients is possible [21-23].

Denosumab has beneficial effects as in case of recurrent ABC described in this report. Surgical endeavours had failed twice and other proven modalities were ruled out. Previous failed surgeries had left the surgeons as well as the patient and relatives in despair with low hopes of further surgeries and in the outlook for newer horizons. We were unable to find a similar report of an aggressive refractory $\mathrm{ABC}$ of the dorsal spine in which deployment of Denosumab was successful. 
Table 1. Published and current cases of Denosumab treatment of ABC.

\begin{tabular}{|c|c|c|c|c|c|c|c|c|}
\hline & Case 1 & Case 2 & Case 3 & Case 4 & Case 5 & Case 6 & Case 7 & Current case \\
\hline Age/sex & 8-year male & 11-year male & 5-year male & 27-year male & 26-year female & 42-year male & 16-year male & 14-year female \\
\hline Location & $\mathrm{C} 5$ & $\mathrm{C} 5$ & Sacrum & Sacrum & C7-T1 & L5-S1 & L5 & D5 \\
\hline Diagnosis & Typical ABC & Typical ABC & Typical ABC & Typical ABC & Typical ABC & Aggressive $A B C$ & Typical ABC & Typical ABC \\
\hline Initial treatment & Surgery & Surgery & None & None & $\begin{array}{l}\text { C4-T4 fixation, } \\
\text { cervical } \\
\text { laminectomy }\end{array}$ & $\begin{array}{l}\text { Seven } \\
\quad \text { consecutive } \\
\text { SAE }\end{array}$ & $\begin{array}{l}\text { Five consecutive } \\
\text { monthly SAEs }\end{array}$ & Surgery twice \\
\hline $\begin{array}{l}\text { Outcome of } \\
\text { initial } \\
\text { treatment }\end{array}$ & $\begin{array}{l}\text { Recurrence at } \\
1 \text { month }\end{array}$ & $\begin{array}{l}\text { Recurrence at } \\
8 \text { months }\end{array}$ & NA & NA & $\begin{array}{l}\text { NA (adjuvant } \\
\text { therapy) }\end{array}$ & $\begin{array}{l}\text { Recurrence at } \\
6 \text { months, } \\
\text { worsening } \\
\text { radiculopathy }\end{array}$ & $\begin{array}{l}\text { Pathologic } \\
\text { vascularity } \\
\text { after } \\
\text { embolisation, } \\
\text { right } \\
\text { sciaticalgia }\end{array}$ & $\begin{array}{l}\text { Recurrence at } \\
2 \text { months }\end{array}$ \\
\hline $\begin{array}{r}\text { Denosumab } \\
\text { treatment }\end{array}$ & $\begin{array}{c}70 \mathrm{mg} / \mathrm{m}^{2} \mathrm{sc} \\
\text { monthly }\end{array}$ & $\begin{array}{l}70 \mathrm{mg} / \mathrm{m}^{2} \mathrm{sc} \mathrm{D} 1,8 \\
15,21,28 \text { and } \\
\text { then monthly }\end{array}$ & $\begin{array}{l}1.2 \mathrm{mg} / \mathrm{kg} / \text { dose sc } \\
\mathrm{D} 1,8,15,21, \\
28 \text { then } \\
\text { monthly }\end{array}$ & $\begin{array}{l}\text { Denosumab } \\
120 \mathrm{mg} \text { sc D1, } \\
8,15,28 \text { and } \\
\text { then monthly } \\
\text { for } 1 \mathrm{yr} \text {., } \\
\text { followed by } \\
\text { observation }\end{array}$ & $\begin{array}{l}120 \mathrm{mg} \mathrm{sc} \\
\text { monthly for } \\
16 \text { months }\end{array}$ & $\begin{array}{l}120 \mathrm{mg} \text { once a } \\
\text { week for } \\
4 \text { weeks } \\
\text { consecutively, } \\
\text { then once every } \\
40 \text { days, } \\
13 \text { Denosumab } \\
\text { administrations }\end{array}$ & $\begin{array}{l}120 \mathrm{mg} \text { once a } \\
\text { week for } \\
4 \text { weeks } \\
\text { consecutively, } \\
\text { then once every } \\
40 \text { days, } \\
11 \text { Denosumab } \\
\text { administrations }\end{array}$ & $\begin{array}{l}\text { Denosumab } 120 \mathrm{mg} \mathrm{sc} \\
\text { D1, 8, 15, } 28 \text { and } \\
\text { then monthly for } \\
6 \text { months, followed } \\
\text { by observation }\end{array}$ \\
\hline $\begin{array}{l}\text { Response to } \\
\text { Denosumab }\end{array}$ & $\begin{array}{l}\text { Recovery from } \\
\text { neurological } \\
\text { symptoms, and } \\
\text { no progression of } \\
\text { ABC, with } \\
\text { evidence of bone } \\
\text { formation on } \\
\text { MRI at } 2 \text { months }\end{array}$ & $\begin{array}{l}\text { Recovery from } \\
\text { neurological } \\
\text { symptoms, and } \\
\text { no progression of } \\
\text { ABC, with } \\
\text { evidence of bone } \\
\text { formation on } \\
\text { MRI at } 4 \text { months }\end{array}$ & $\begin{array}{l}\text { Resolution of pain } \\
\text { and new bone } \\
\text { formation with } \\
\text { healing of } \\
\text { pathologic } \\
\text { fracture on } \\
\text { MRI }\end{array}$ & $\begin{array}{l}\text { Resolution of pain } \\
\text { and new bone } \\
\text { formation on } \\
\text { CT scan, } \\
\text { decrease in } \\
\text { giant cells, and } \\
\text { decrease in } \\
\text { cellularity of } \\
\text { fibrous stroma }\end{array}$ & $\begin{array}{l}\text { Persistence of } \\
\text { C8-T1 deficit, } \\
\text { peripheral bone } \\
\text { reconstruction, } \\
\text { decrease in } \\
\text { tumour size and } \\
\text { bone fusion at } \\
19.5 \text { months } \\
\text { follow-up }\end{array}$ & $\begin{array}{l}\text { Complete } \\
\text { ossification at } \\
35 \text { months CT } \\
\text { scan. Pain-free }\end{array}$ & $\begin{array}{l}\text { gradual mass } \\
\text { reduction and } \\
\text { progressive } \\
\text { ossification } \\
\text { since the } 3 \text { rd } \\
\text { month of } \\
\text { administration. } \\
33 \text { months } \\
\text { follow-up }\end{array}$ & $\begin{array}{l}\text { Resolution of pain and } \\
\text { new bone formation } \\
\text { on MRI scan, } \\
\text { complete recovery } \\
\text { of neurologic } \\
\text { worsening. No } \\
\text { recurrence at } \\
1.5 \text { year follow-up }\end{array}$ \\
\hline Follow-up & 2 months & 4 months & 12 months & 12 months & 19.5 months & 35 months & 33 months & 24 months \\
\hline References & Lange et al. [6] & Lange et al. [6] & $\begin{array}{l}\text { Pelle } \\
\quad \text { et al. [17] }\end{array}$ & $\begin{array}{l}\text { Skubitz } \\
\quad \text { et al. [13] }\end{array}$ & $\begin{array}{l}\text { Arnaud Dubory } \\
\text { et al. [15] }\end{array}$ & $\begin{array}{l}\text { Ghermandi } \\
\text { et al. [14] }\end{array}$ & $\begin{array}{l}\text { Ghermandi } \\
\text { et al. [14] }\end{array}$ & \\
\hline
\end{tabular}

Note: ABC indicates aneurysmal bone cyst; SAE, Selective Arterial Embolisation; NA, not applicable; CT, computed tomographic; MRI, magnetic resonance image; sc, sub-cutaneous. 


\section{Conclusion}

We conclude that the usage of Denosumab, although based on anecdotal experiences, may be an excellent option in cases not amenable to surgical interventions and frequent recurrences. Long-term results should confirm these preliminary outcomes to standardise the treatment-guidelines.

\section{Conflict of interest}

There is no conflict of interest among the authors or the institution regarding the manuscript, the scientific work or data collection. The legal regulatory status of the device(s)/drug(s) that is/are the subject of this manuscript is not applicable in our country. No funds were received in support of this work. No benefits in any form have been or will be received from a commercial party related directly or indirectly to the subject of this manuscript. There was no breach of ethical issues by any of the authors mentioned. The manuscript has been read and approved by the authors and each one of the authors treat their work trust worthy within all ethical parameters.

\section{References}

1. Burch S, Hu S, Berven S (2008) Aneurysmal bone cysts of the spine. Neurosurg Clin N Am 19, 41-47.

2. Boriani S, De Iure F, Campanacci L, et al. (2001) Aneurysmal bone cyst of the mobile spine: report on 41 cases. Spine 26, 27-35.

3. Leithner A, Windhager R, Lang S, et al. (1999) Aneurysmal bone cyst. A population based epidemiologic study and literature review. Clin Orthop Relat Res 363, 176-179.

4. Zileli M, Isik HS, Ogut FE, et al. (2013) Aneurysmal bone cysts of the spine. Eur Spine J 22, 593-601.

5. Lim JB, Sharma H, Reid R, et al. (2012) Aneurysmal bone cysts of the vertebrae. J Orthop Surg (Hong Kong) 20, 201-204.

6. Lange T, Stehling C, Frohlich B, et al. (2013) Denosumab: a potential new and innovative treatment option for aneurysmal bone cysts. Eur Spine J 22, 1417-1422.

7. Lau AW, Pringle LM, Quick L, et al. (2010) TRE17 (ubiquitinspecific protease 6 (USP6) oncogene translocated in aneurysmal bone cyst blocks osteoblastic maturation via an autocrine mechanism involving bone morphogenetic protein dysregulation. J Biol Chem 285, 37111-37120.

8. Oliveira AM, Chou MM, Perez-Atayde AR, Rosenberg AE (2006) Aneurysmal bone cyst: a neoplasm driven by upregulation of the USP6 oncogene. J Clin Oncol 24(1), e1.
9. Chawla S, Henshaw R, Seeger L, et al. (2013) Safety and efficacy of Denosumab for adults and skeletally mature adolescents with giant cell tumour of bone: interim analysis of an open-label, parallel group, phase 2 study. Lancet Oncol 14, 901-908.

10. Martin-Broto J, Cleeland CS, Glare PA, et al. (2014) Effects of Denosumab on pain and analgesic use in giant cell tumour of bone: interim results from a phase II study. Acta Oncol 53, 1173-1179.

11. Skubitz KM (2014) Giant cell tumour of bone: current treatment options. Curr Treat Options Oncol 15, 507-518.

12. Taylor RM, Kashima TG, Hemingway FK, et al. (2012) CD14mononuclear stromal cells support (CD14R) monocyte-osteoclast differentiation in aneurysmal bone cyst. Lab Invest 92, 600-605.

13. Skubitz Keith M, Peltola Justin C, Santos Edward R, et al. (2015) Response of aneurysmal bone cyst to denosumab. Spine 40(22), E1201-E1204.

14. Ghermandi R, Terzi S, Gasbarrini A, Boriani S (2016) Denosumab: non-surgical treatment option for selective arterial embolization resistant aneurysmal bone cyst of the spine and sacrum. Case report. Eur Rev Med Pharmacol Sci 20, 3692-3695.

15. Dubory Arnaud, Missenard Gilles, Domont Julien, et al. (2016) Interest of Denosumab for the treatment of giant-cells tumors and aneurysmal bone cysts of the spine. About nine cases. Spine 41(11), E654-E660.

16. Pauli C, Fuchs B, Pfirrmann C, et al. (2014) Response of an aggressive periosteal aneurysmal bone cyst $(\mathrm{ABC})$ of the radius to Denosumab therapy. World J Surg Oncol 12, 17.

17. Pelle DW, Ringler JW, Peacock JD, et al. (2014) Targeting receptor activator of nuclear kappa ligand in aneurysmal bone cysts: verification of target and therapeutic response. Transl Res 164, 139-148.

18. Henry DH, Costa L, Goldwasser F, et al. (2011) Randomized, double-blind study of Denosumab versus zoledronic acid in the treatment of bone metastases in patients with advanced cancer (excluding breast and prostate cancer) or multiple myeloma. J Clin Oncol 29, 1125-1132.

19. Smith MR, Saad F, Coleman R, et al. (2012) Denosumab and bone metastasis-free survival in men with castration-resistant prostate cancer: results of a phase 3, randomised, placebocontrolled trial. Lancet 379, 39-46.

20. Stopeck AT, Lipton A, Body JJ, et al. (2010) Denosumab compared with zoledronic acid for the treatment of bone metastases in patients with advanced breast cancer: a randomized, double-blind study. J Clin Oncol 28, 5132-5139.

21. Karras NA, Polgreen LE, Ogilvie C, et al. (2013) Denosumab treatment of metastatic giant-cell tumour of bone in a 10 -yearold girl. J Clin Oncol 31, e200-e202.

22. Whyte MP, Wenkert D, Clements KL, et al. (2003) Bisphosphonate induced osteopetrosis. N Engl J Med 349, 457-463.

23. Kobayashi E, Setsu N (2015) Osteosclerosis induced by Denosumab. Lancet 385, 539. 